\title{
Insights into the Positive Effect of Pyraclostrobin on Sugarcane Productivity
}

\author{
Amanda Moreira Lopes ${ }^{1}$, Pedro Vitor Schumacher ${ }^{1}$, Aurora Terylene Pérez Martínez ${ }^{2}$, \\ Antônio Paulino da Costa Netto ${ }^{3}$ and Antonio Chalfun-Junior 1 ,* id \\ 1 Departamento de Biologia, Setor de Fisiologia Vegetal, Universidade Federal de Lavras, Lavras 37200-000, \\ Brasil; amandamlbio@gmail.com (A.M.L.); pedro_schumacher@hotmail.com (P.V.S.) \\ 2 Centro de Bioplantas, Universidad de Ciego de Avila, Ciego de Avila 65200, Cuba; aperez@bioplantas.cu \\ 3 Regional Jataí, Unidade Acadêmica Especial de Ciências Biológicas, Universidade Federal de Goiás, \\ Jataí 75800-000, Brasil; apcnetto@gmail.com \\ * Correspondence: chalfunjunior@dbi.ufla.br; Tel.: +55-3538291887
}

Received: 25 May 2018; Accepted: 16 July 2018; Published: 18 July 2018

\begin{abstract}
Achieving high yields is a challenge for sugarcane producers due to the diverse environmental conditions to which the crop is subjected. In tropical and subtropical regions, where sugarcane is typically cultivated, crop diseases are common. This necessitates the development of disease management techniques. Among these techniques, chemical control is of particular significance due to the development of new antifungal agents, such as pyraclostrobin. For some crops, pyraclostrobin has a positive influence on yield due to its effects on plant physiology. The aim of this study was to evaluate the physiological responses and yield of three sugarcane cultivars treated with the fungicide, pyraclostrobin. The experiment was performed in a randomized block design (RBD) with a split-plot arrangement; the variables analyzed were the application or non-application of fungicide in the plots and, in the subplots, the evaluation times after fungicide application. Both the rate of photosynthesis and the antioxidant enzyme (Superoxide Dismutase, Catalase and Ascorbate Peroxidades) activity increased in plants treated with fungicide in comparison to untreated plants, and in the RB855156 cultivar the stomatal conductance, transpiration, and nocturnal respiratory rate were increased. Furthermore, application of pyraclostrobin increased stalk yield and the green biomass index in the RB855156 and RB86751 sugarcane cultivars. In certain cultivars of sugarcane, application of pyraclostrobin leads to an increased yield.
\end{abstract}

Keywords: physiological effect; strobilurins; yield; gas exchange; antioxidant enzymes; Saccharum officinarum

\section{Introduction}

The use of bioenergy as a promising alternative to mitigate the effects of climate change by reducing $\mathrm{CO}_{2}$ emissions has received strong support from governmental and non-governmental agencies worldwide. Due to the various problems associated with the use of fossil fuels and other non-renewable resources, there is increased interest in bioenergy around the globe $[1,2]$. The substitution of bioenergy for fossil and other nonrenewable energy resources brings several economic and environmental advantages [3]. Such a resource can be used both for energy generation and for liquid fuel production [4].

Among the renewable energy sources, sugarcane (Saccharum spp.) is of particular significance because it is an important source of both bioenergy and food; sugarcane is economically important in several tropical and subtropical countries [5]. In these regions, the species is seen as being highly productive despite the fact that its cultivation is subjected to diverse environmental conditions that 
can affect its growth, development, and, hence, productivity [6,7]. Due to the importance of this crop, we must develop new technologies aimed at guaranteeing high yields.

Strobilurins are an important class of fungicides that act on the mitochondrial respiration of fungi by blocking the electron transport chain [8]. Research on this fungicide class has opened new perspectives for the control of plant disease, considering the advantages obtained by the positive physiological effects observed in plants treated with these molecules [9]. Initial studies have demonstrated that the effects of strobilurins include increased growth and biomass production, reduced leaf senescence, increased nitrate absorption, regulation of the levels of certain hormones under stress conditions, oxidative stress relief, and yield gains [10].

In fungi, strobilurins inhibit mitochondrial respiration by blocking electron transfer in complex III (complex bc1) of the mitochondrial electron transport chain [11]. In plants, the bc1 complex is also present in mitochondria, so at least partial inhibition of this complex should be expected after fungicide absorption. The transient influence of strobilurins on mitochondria would not cause phytotoxicity because it is determined by the importance of mitochondrial respiration for energy supply, which varies due to environmental conditions and the plant's phenological stage [12]. Despite the large number of studies, no evidence of any direct interaction of strobilurin with enzymes or receptor systems beyond mitochondrial respiration has been verified [13].

Pyraclostrobin belongs to the strobilurin class and stands out as having a broad spectrum of action and potent fungicidal activity, which are the main characteristics that allow the product to contribute to high yields. Moreover, it has positive effects on crop yield due to its impact on plant physiology [14]. In healthy barley and wheat plants, the application of pyraclostrobin promotes growth and increases yield and quality $[9,13]$.

Studies aiming to evaluate the positive effects of pyraclostrobin application on plants have been conducted with several different crops. In soybeans, Fagan et al. [15] reported that the application of fungicide at the crop's flowering stage increased the rate of photosynthesis and decreased the respiratory rate. In maize, a species close to sugarcane, strobilurins generally show effects that boost crop yield [16,17]. However, according to Costa et al. [18], in conditions of low disease severity, maize cultivars treated with these fungicides show inconsistent yield results, unlike cases where disease incidence is high.

In sugarcane, strobilurins are indicated for the control of leaf spots; however, their effects on the plant's physiology are still unknown. Therefore, the aim of this study was to evaluate the physiological responses and yield of three sugarcane cultivars treated with pyraclostrobin, a fungicide belonging to the strobilurin class.

\section{Materials and Methods}

The experiment was conducted in 2013 and 2014 at the Center for Scientific and Technological Development in Agriculture of the Federal University of Lavras/UFLA-Fazenda Muquém, in the municipality of Lavras-MG, Brazil, $21.198551^{\circ} \mathrm{S}, 44.982641^{\circ} \mathrm{W}$, at $940 \mathrm{~m}$ elevation. The soil of the experimental area has a clayey texture, and the climate of the region is classified as humid subtropical (Cwa), with a rainy season in the summer and a drought season in the winter [19]. Meteorological data (precipitation and temperature) during the experiment are presented in Figure 1.

The cultivars used for the experiment were RB855156, RB867515, and RB92579, which were chosen for one experiment each because they have different maturation periods and differentiated phenological development. Each experiment was performed with a randomized block design (RBD) in the split-plot arrangement; the variables analyzed were the application or non-application of the fungicide pyraclostrobin in the plots and, in the subplots, the evaluation times, with three replicates. Gas exchange evaluations were performed at $0,1,2,4,5,15,25,35$, and 65 days after application (DAA). Enzymatic analyses, chlorophyll content, carotenoid measurement, and biometric analyses (plant height, number of green leaves per plant, and stalk diameter) were performed at 0, 5, 15, 25, 35, and 65 DAA. For the determination of yield indexes (tons of cane per hectare (TCH) and green mass) 
only, the experiment was conducted in an RBD without the use of an experimental arrangement, thus, containing two treatments and three replicates. The experimental unit consisted of three 10-m linear rows spaced $1.5 \mathrm{~m}$ apart.

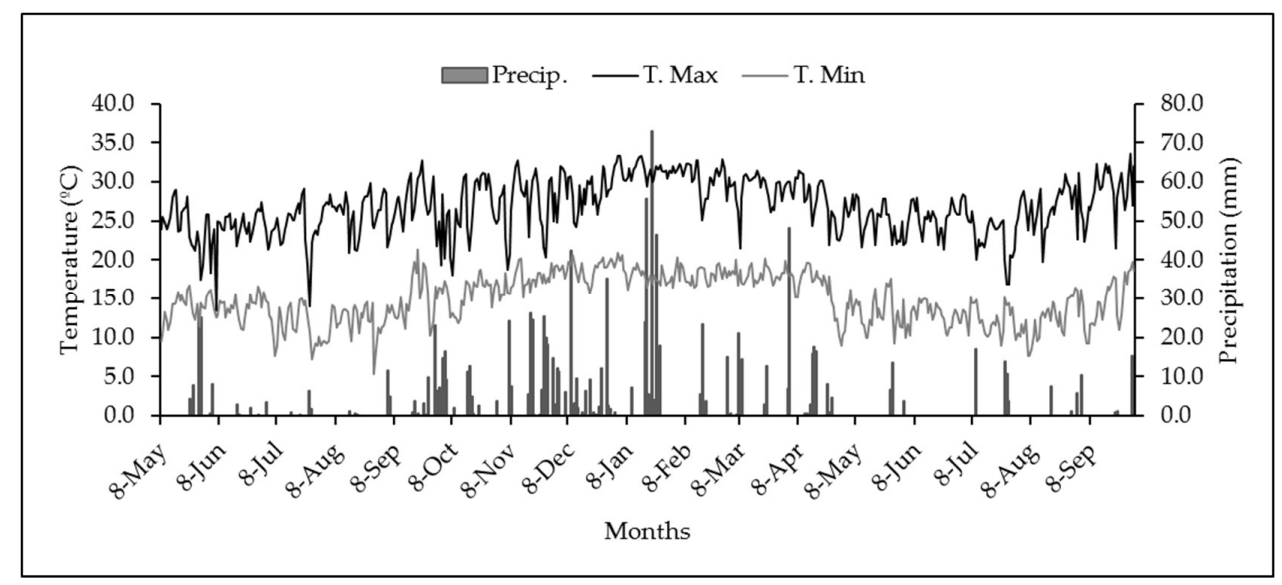

Figure 1. Temperature and precipitation during the experiment conduction.

All cultivars were planted on 8 May 2013, with a density of 100,000 plants ha ${ }^{-1}$. The experimental area was prepared with grooves $0.25 \mathrm{~m}$ deep, in which an average of 15 gems per linear meter were deposited. During the entire period of the experiment, the experimental area was monitored for pests and weeds, which were controlled whenever necessary by mechanical control for weeds and application of insecticides for pests.

The fungicide, pyraclostrobin (Opera ${ }^{\circledR}$, Ludwigshafen, RP, Germany), was applied nine months after planting, in the maturation stage when the pressure of diseases can appear (no disease was observed during the experimental time), using a $\mathrm{CO}_{2}$-pressurized backpack sprayer (Herbicat, Catanduva, SP, Brazil) equipped with a TeeJet AIXR11002 nozzle (TeeJet Technologies, Wheaton, IL, USA), with a space of $0.5 \mathrm{~m}$ among nozzles at a pressure of 2 bar. The syrup volume was proportional to $150 \mathrm{~L}$ per hectare and the control plants were sprayed with water in the same proportion as the syrup. The dose of $1.0 \mathrm{~L} \mathrm{ha}^{-1}$ (133 $\mathrm{g}$ L of a.i.), as indicated by the manufacturer, was used.

Gas exchange in fully expanded leaves (leaves +3) was quantified using a portable open gas-exchange infrared gas analyzer (IRGA) (model LI-6400, LI-COR ${ }^{\circledR}$, Lincoln, NE, USA). The parameters measured were the net rate of photosynthesis (A), stomatal conductance (gs), and transpiration (E), and were taken between 9 and $11 \mathrm{~h}$ (solar time). An artificial photon saturation (1500 $\mu \mathrm{mol} \mathrm{m} \mathrm{m}^{-2} \mathrm{~s}^{-1}$, which was determined by a light curve performed previously) was applied at an ambient concentration of $\mathrm{CO}_{2}$. Nocturnal measurements were also performed between 9 p.m. and 11 p.m. to quantify the respiratory rate.

To quantify the antioxidant enzymes, the enzymatic extract was obtained by maceration of the collected material (three or more leaves) in liquid nitrogen. To $50 \mathrm{mg}$ of fresh material we added $1.5 \mathrm{~mL}$ of extraction buffer, containing $400 \mathrm{mM}$ potassium phosphate buffer (pH 7.8), $10 \mathrm{mM}$ EDTA, and $20 \mathrm{mM}$ ascorbic acid. The extract was centrifuged at $13,000 \mathrm{~g}$ for $10 \mathrm{~min}$ at $4{ }^{\circ} \mathrm{C}$ and the supernatant was collected and stored at $-20{ }^{\circ} \mathrm{C}$ during the analysis period. The collected supernatants were used for the enzymatic analyses of superoxide dismutase (SOD), catalase (CAT), and ascorbate peroxidase $(\mathrm{APX})[20]$.

SOD activity was assessed by the ability of the enzyme to inhibit the photoreduction of nitro blue tetrazolium chloride (NBT), and results was represent in units of enzimes where one unit of SOD as the amount that inhibits the NBT photoreduction by 50\%, according to Giannopolitis and Ries [21]. CAT activity was evaluated according to the decrease in the absorbance of $\mathrm{H}_{2} \mathrm{O}_{2}$ according to the protocol proposed by Mengutay et al. [22]. APX activity was determined by monitoring the ascorbate oxidation rate at $290 \mathrm{~nm}$ every $15 \mathrm{~s}$ for $3 \mathrm{~min}$ [23]. 
Total chlorophyll contents were measured in extracts obtained after maceration of $0.1 \mathrm{~g}$ of fresh leaf matter from the upper and lower portions. The samples were macerated in a mortar with $5 \mathrm{~mL}$ of acetone $(80 \%)$. The extract was then filtered, and the volume was normalized to $10 \mathrm{~mL}$ of water in a dark room maintained with green light. The extracts were measured at the wavelengths of $663 \mathrm{~nm}$ and $645 \mathrm{~nm}$ to calculate the ratio of chlorophyll $a$ to chlorophyll $b$. Total carotenoids were quantified at the wavelength of $470 \mathrm{~nm}$ [24]. The chlorophyll $a / b$ ratio and carotenoid levels were determined according to the equations described by Lichtenthaler [25].

Evaluations related to harvest indices were made according to the cycle of each cultivar. Cultivars were evaluated and harvested on the following dates: RB855156 on 29 May 2014; RB92579 on 28 July 2014; and RB867515 on 1 October 2014. Before harvesting, plant height was measured with the aid of a measuring tape, stalk diameter was measured using a digital caliper, and the green leaves were counted. These measurements were performed with 10 plants in each experimental unit. After these quantifications, plants were harvested, and 10 linear meters of the central row from each experimental unit were collected. Measurements of green mass and TCH were performed with the aid of a portable scale, with the results extrapolated to tons per hectare $\left(\mathrm{t} \mathrm{ha}^{-1}\right)$.

All data were submitted to an analysis of variance by the $\mathrm{F}$ test, and the averages were compared with the Tukey test, both at a $5 \%$ probability.

\section{Results and Discussion}

\subsection{Gas Exchange}

In terms of gas exchange (rate of photosynthesis, stomatal conductance, transpiration, and respiration rate), there was no significant interaction between the evaluation times and the application or non-application of the fungicide. The three cultivars experienced an increase in the rate of photosynthesis due to pyraclostrobin application, regardless of the evaluation time (Figure 2a). However, only cultivar RB855156 had an altered stomatal conductance, transpiration, and respiratory rate due to pyraclostrobin application (Figure $2 b-d$ ).

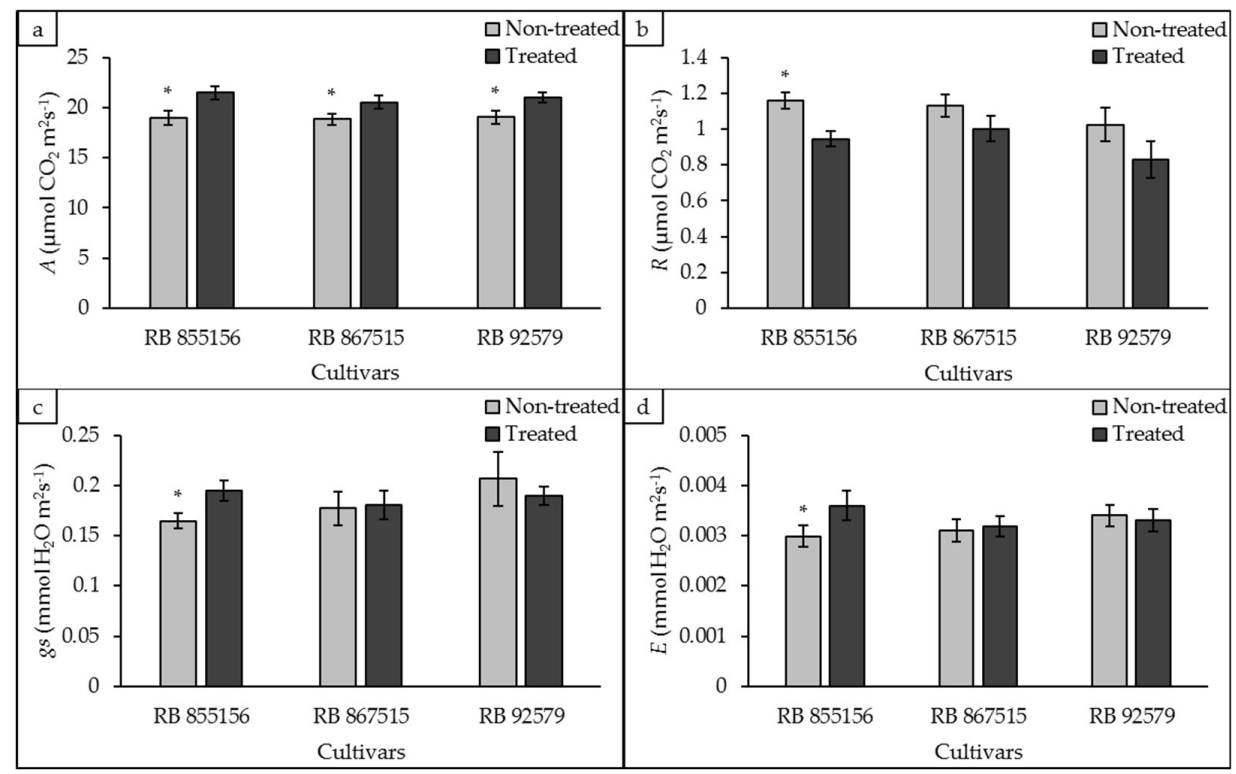

Figure 2. (a) Rate of photosynthesis (A), (b) stomatal conductance (gs), (c) transpiration (E), and (d) nocturnal respiratory rate in three sugarcane cultivars treated with the fungicide, pyraclostrobin, in comparison with a control. The results represent the average of nine evaluation times and three replications. * Indicates a significant difference among treatments by the Tukey test at $5 \%$ probability. The bar indicates the standard error of the mean. 
The rate of photosynthesis increased due to application of pyraclostrobin by approximately $13 \%$ in cultivar RB855156, 9\% in RB867515, and 10\% in RB92579 relative to plants that did not receive pyraclostrobin (Figure 2a). When comparing to $\mathrm{C} 3$ carbon assimilation plants, an increase in the rate of photosynthesis in these plants can be explained by a change in the $\mathrm{CO}_{2}$ compensation point $[15,26]$. However, sugarcane shows a mechanism of carbon concentration typical of its $\mathrm{C} 4$ metabolism, which makes its $\mathrm{CO}_{2}$ compensation point close to zero, thus, reflecting low levels of photorespiration [27]. Therefore, pyraclostrobin likely acts on other metabolic aspects of $\mathrm{C} 4$ plants to increase the rate of photosynthesis.

The cultivar, RB855156, showed greater stomatal conductance and transpiration due to the application of pyraclostrobin (Figure $2 b$,c), indicating a greater exchange with the environment with increasing photosynthesis; this can be observed in Figure 2a. The relationship among these factors can be explained by the increase in $\mathrm{CO}_{2}$ consumption resulting from the increased rate of photosynthesis, causing a reduction of the internal $\mathrm{CO}_{2}$ concentration. This reduction may induce stomatal opening, allowing greater diffusion of $\mathrm{CO}_{2}$ from the atmosphere to the substomatal cavity, as observed in Figure 2. Consequently, we detected higher transpiration in these plants, as observed for this same cultivar (Figure 2c), because the stomata are responsible for $\mathrm{CO}_{2}$ input from the atmosphere to the plants and simultaneously enable the loss of water [28].

The nocturnal respiratory rate decreased by approximately $18 \%$ in the plants from the cultivar, RB855156, that were treated with the fungicide (Figure 2b). In fungi, pyraclostrobin acts by blocking the transport of electrons in the mitochondrial respiratory chain [8]. It is possible that this same effect occurs in plants, although this effect is more pronounced in mitochondria isolated from fungi than in mitochondria isolated from plants $[13,15]$.

\subsection{Chlorophyll Contents}

The chlorophyll $a / b$ ratio and the total carotenoid content showed a significant interaction between the application of pyraclostrobin and the evaluation times in the cultivars, RB855156 and RB92579. However, the cultivar, RB867515, did not show an interaction between the application of pyraclostrobin and the evaluation time, nor did the application of pyraclostrobin change the chlorophyll $a / b$ ratio or the carotenoid content.

In the cultivar, RB855156 (Table 1), the chlorophyll $a / b$ ratio was lower in the control plants at 5 and 15 DAA than in the plants treated with pyraclostrobin. We observed an increase in the chlorophyll $a / b$ ratio in the treated plants over time.

Table 1. Chlorophyll $a / b$ ratio and total carotenoid content in the cultivar, RB855156.

\begin{tabular}{ccccc}
\hline \multirow{2}{*}{ Time $^{\mathbf{1}}$} & \multicolumn{2}{c}{ Chlorophyll $\boldsymbol{a} / \boldsymbol{b}$ Ratio (Chlorophyll $\mathbf{g}^{\mathbf{- 1}} \mathbf{F M )}$} & Carotenoid Content $\left(\boldsymbol{\mu g}\right.$ Carotenoids $\left.\mathbf{~}^{-\mathbf{1}} \mathbf{F M}\right)$ \\
\cline { 2 - 5 } & Non-Treated & Treated & Non-Treated & Treated \\
\hline 0 & $2.96 \mathrm{aA}{ }^{*}$ & $2.85 \mathrm{cA}$ & $2.81 \mathrm{aB}$ & $4.17 \mathrm{aA}$ \\
5 & $3.02 \mathrm{aA}$ & $3.26 \mathrm{bcA}$ & $2.52 \mathrm{aA}$ & $2.40 \mathrm{bA}$ \\
15 & $3.39 \mathrm{aB}$ & $3.96 \mathrm{abA}$ & $3.53 \mathrm{aA}$ & $2.62 \mathrm{bA}$ \\
25 & $3.38 \mathrm{aB}$ & $4.18 \mathrm{aA}$ & $2.62 \mathrm{aA}$ & $2.27 \mathrm{bA}$ \\
35 & $3.54 \mathrm{aA}$ & $3.15 \mathrm{bcA}$ & $1.02 \mathrm{bA}$ & $1.65 \mathrm{bA}$ \\
65 & $3.72 \mathrm{aA}$ & $4.11 \mathrm{aA}$ & $3.68 \mathrm{aA}$ & $2.70 \mathrm{bB}$ \\
\hline
\end{tabular}

${ }^{1}$ Days after pyraclostrobin application. ${ }^{*}$ Averages followed by the same lowercase letter on the columns and capital on the rows do not differ among one another by the Tukey test at $5 \%$ probability. FM: Fresh matter.

The chlorophyll $a / b$ ratio in the cultivar, RB92579, (Table 2) did not show significant differences among the times and treatments evaluated. The total carotenoid content showed a significant decrease over time for plants treated with pyraclostrobin. With respect to the difference between the treated and non-treated plants, the chlorophyll content increased due to pyraclostrobin application at 5 DAA and remained the same until $65 \mathrm{DAA}$, when it was reduced in relation to the control plants. 
Table 2. Chlorophyll $a / b$ ratio and total carotenoid content in the cultivar, RB92579.

\begin{tabular}{ccccc}
\hline \multirow{2}{*}{ Time $^{\mathbf{1}}$} & \multicolumn{2}{c}{ Chlorophyll $\boldsymbol{a} / \boldsymbol{b}$ Ratio $\left(\boldsymbol{\mu g}\right.$ Chlorophyll $\left.\mathbf{~}^{-\mathbf{1}} \mathbf{F M}\right)$} & \multicolumn{2}{c}{ Carotenoid Content $\left(\boldsymbol{\mu g}\right.$ Carotenoids $\mathbf{~}^{\mathbf{- 1}} \mathbf{F M )}$} \\
\cline { 2 - 5 } & Non-Treated & Treated & Non-Treated & Treated \\
\hline 0 & $2.94 \mathrm{aA}{ }^{*}$ & $2.54 \mathrm{aA}$ & $3.53 \mathrm{aA}$ & $3.01 \mathrm{abA}$ \\
5 & $3.17 \mathrm{aA}$ & $2.97 \mathrm{aA}$ & $2.53 \mathrm{bcB}$ & $3.65 \mathrm{aA}$ \\
15 & $3.72 \mathrm{aA}$ & $3.59 \mathrm{aA}$ & $2.78 \mathrm{abA}$ & $3.67 \mathrm{aA}$ \\
25 & $3.75 \mathrm{aA}$ & $3.88 \mathrm{aA}$ & $2.49 \mathrm{bcA}$ & $2.39 \mathrm{bcA}$ \\
35 & $3.03 \mathrm{aA}$ & $2.85 \mathrm{aA}$ & $1.67 \mathrm{cA}$ & $1.42 \mathrm{cA}$ \\
65 & $3.60 \mathrm{aA}$ & $3.72 \mathrm{aA}$ & $3.66 \mathrm{aA}$ & $2.52 \mathrm{bB}$ \\
\hline
\end{tabular}

${ }^{1}$ Days after pyraclostrobin application. ${ }^{*}$ Averages followed by the same lowercase letter on the columns and capital on the rows do not differ among one another by the Tukey test at $5 \%$ probability. FM: Fresh matter.

The higher chlorophyll $a / b$ ratio was related directly, in this case, to the increase in the rate of photosynthesis. A higher chlorophyll $a / b$ ratio promotes greater efficiency of radiation uptake, thus, favoring better performance of the biochemical stage of photosynthesis, since there was also increased transpiration and stomatal conductance. In addition, the increase in chlorophyll $a / b$ content in the treated plants may be correlated with a change in nitrogen metabolism. Some studies report an increase in nitrate reductase enzyme activity in plants treated with pyraclostrobin $[15,29]$, thus, resulting in an enhanced use of nitrogen, which is necessary for chlorophyll synthesis.

Carotenoids act as accessory pigments, playing a key role, together with xanthophylls, in photoprotection and acting directly on the thermal dissipation of energy [30]. The increase in this pigment observed five days after the application of pyraclostrobin in the cultivar, RB92579, (Table 2) may indicate an increasing tolerance of these plants to an excess of luminosity. However, at most time points and in all cultivars, pyraclostrobin had little influence on the total carotenoid content, which may indicate that the greater use of light energy is not closely related to the photoprotection activity of carotenoids, as observed in the plants that received pyraclostrobin.

\subsection{Antioxidant System}

The enzyme activity of the antioxidant system, SOD, CAT, and APX, showed no significant interaction between the evaluation time and the application or non-application of pyraclostrobin. However, there was a significant difference in antioxidant enzyme activity between pyraclostrobin-treated plants and non-treated plants for all three cultivars. Plants treated with pyraclostrobin showed higher enzymatic activity than plants not treated with the fungicide (Figures 3-5).

There was a direct relationship between the increase in antioxidant enzyme activity and the increased rate of photosynthesis. Since there is oxygen production in the chloroplasts during photosynthesis, a molecule can receive electrons that pass through the photosystems, thus, forming reactive oxygen species (ROS). Seeking to reestablish the ROS balance, the plants produce antioxidant enzymes to eliminate the excess ROS, thus, preventing damage caused by an excess of these radicals [31].

The increased activity of antioxidant enzymes caused by the application of pyraclostrobin may be one of the factors that acts in the reduction of leaf senescence, as shown in Figure 6; the plants from the cultivars, RB855156 and RB867515, which received the application of pyraclostrobin, showed a higher number of green leaves. Furthermore, the increased activity of these enzymes can prevent the degradation of chlorophyll molecules because antioxidant enzymes decrease the production of ROS, thus, preventing them from causing damage to proteins and cellular structures [32]. This explains the increase in the chlorophyll $a / b$ ratio in the cultivar, RB855156. 


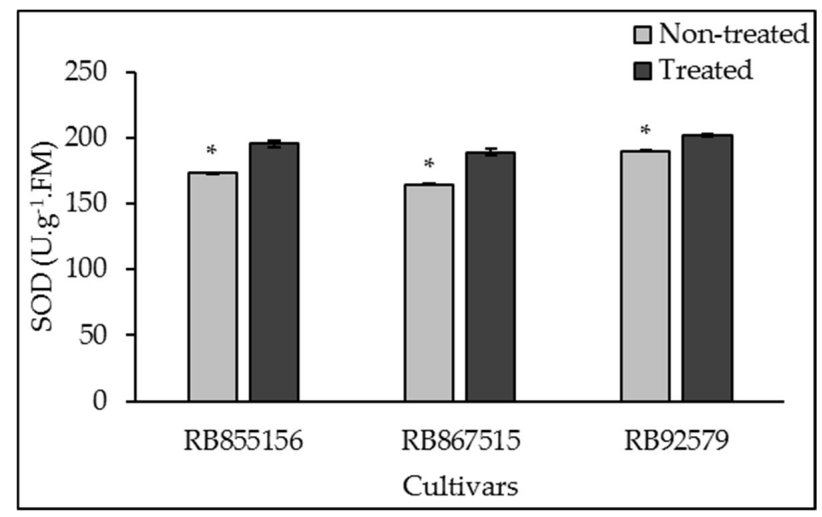

Figure 3. Activity of the superoxide dismutase (SOD) enzyme in sugarcane plants treated with pyraclostrobin in relation to control plants. The results represent the average of six evaluation times and three replications. * Indicates a significant difference among treatments by the Tukey test at $5 \%$ probability. The bar indicates the standard error of the mean. FM: Fresh matter; U: SOD unit.

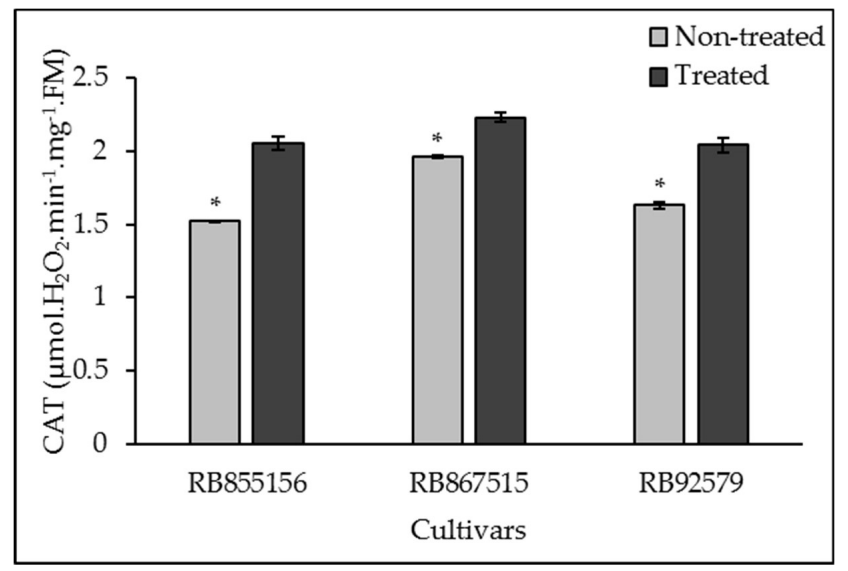

Figure 4. Activity of the catalase (CAT) enzyme in sugarcane plants treated with pyraclostrobin in relation to control plants. The results represent the average of six evaluation times and three replications. * Indicates a significant difference among treatments by the Tukey test at $5 \%$ probability. The bar indicates the standard error of the mean. FM: Fresh matter.

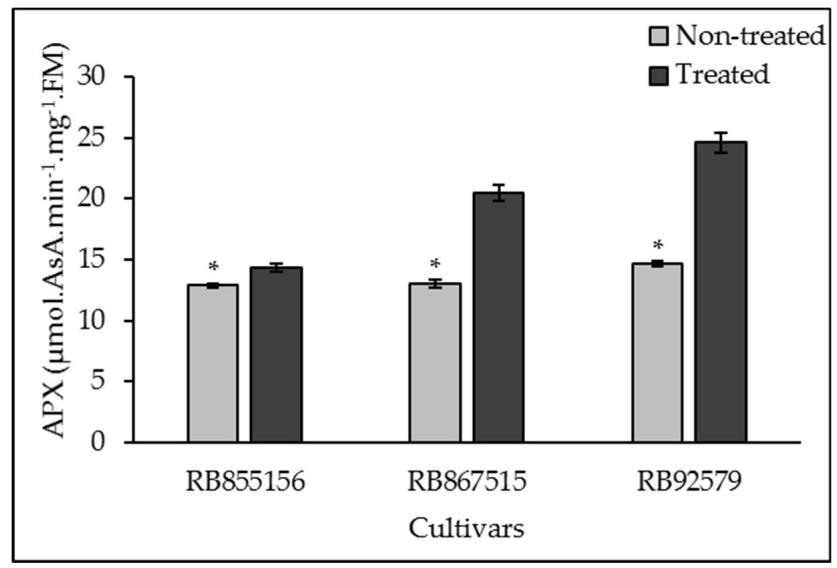

Figure 5. Activity of the ascorbate peroxidase (APX) enzyme in sugarcane plants treated with pyraclostrobin in relation to control plants. The results represent the average of six evaluation times and three replications. * Indicates a significant difference among treatments by the Tukey test at $5 \%$ probability. The bar indicates the standard error of the mean. FM: Fresh matter. 


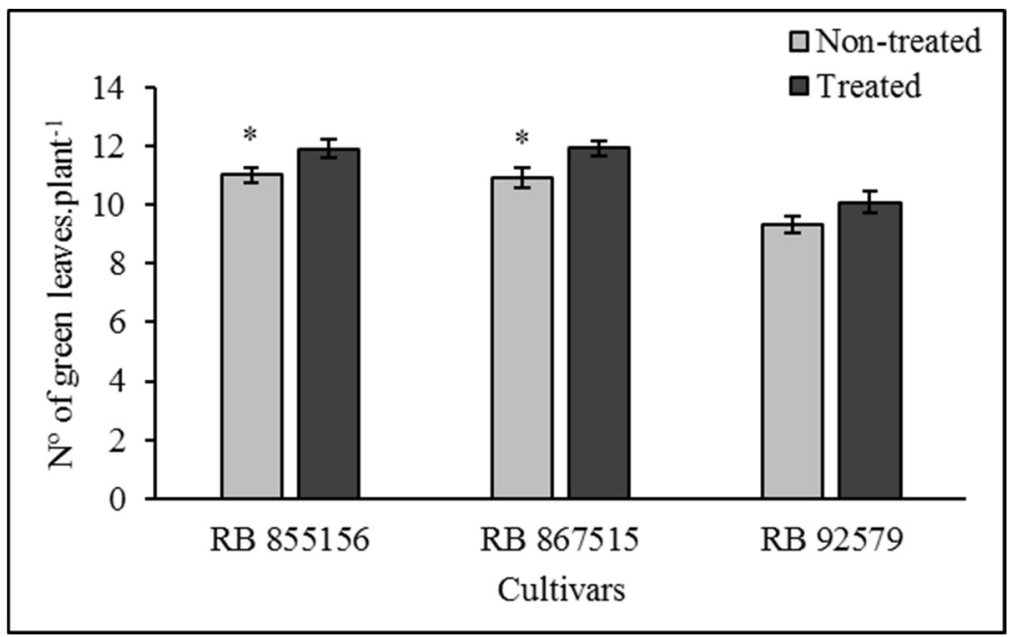

Figure 6. Average number of green leaves in sugarcane plants treated with the fungicide, pyraclostrobin, compared to control plants. The results represent the average of six evaluation times and three replications. * Indicates a significant difference among treatments by the Tukey test at $5 \%$ probability. The bar indicates the standard error of the mean.

\subsection{Biometric Analyses}

Among the three cultivars evaluated in our experiments, only RB92579 did not show a change in the average number of green leaves per plant due to the application of pyraclostrobin (Figure 6). The other cultivars showed an increase in the average number of green leaves per plant when pyraclostrobin was applied. This can be explained by the already reported effect of pyraclostrobin on ethylene synthesis in plants. This fungicide is able to inhibit ethylene synthesis, thus, delaying leaf senescence and increasing the period in which the leaves remain photosynthetically active, which can increase yield even over a short period of time $[9,15]$.

Biometric analyses of plant growth, plant height, and stalk diameter did not show any interaction between the evaluation times and the application or non-application of pyraclostrobin. However, application of pyraclostrobin had a significant effect on these variables: Cultivars, RB855156 and RB92579, showed greater height when subjected to fungicide application, and all three cultivars showed a larger stalk diameter when subjected to this treatment (Figure 7a,b).

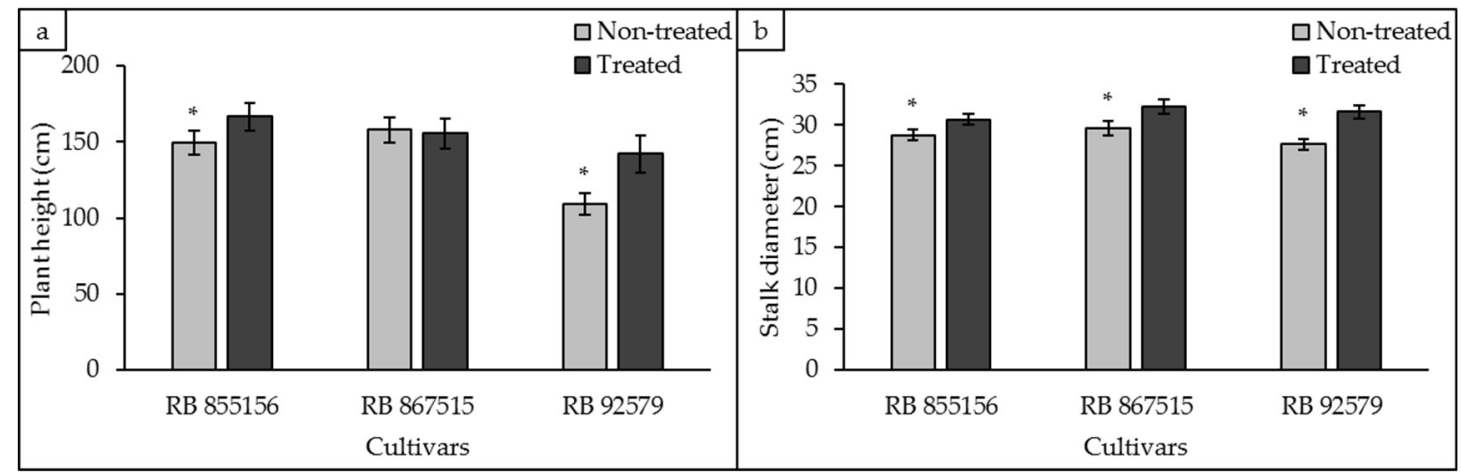

Figure 7. (a) Height and (b) stalk diameter of sugarcane plants treated with the fungicide, pyraclostrobin, in relation to control plants. The results represent the average of six evaluation times and three replications. * Indicates a significant difference among treatments by the Tukey test at $5 \%$ probability. The bar indicates the standard error of the mean. 
The increase in the rate of photosynthesis caused by the application of pyraclostrobin may lead to an increase in the production of photoassimilates, which guarantees greater development in the plants treated with the fungicide, as demonstrated here by the greater plant height (Figure 7a) and stalk diameter (Figure $7 \mathrm{~b}$ ) of these plants. Moreover, the change in the synthesis of some hormones, such as abscisic acid, caused by the application of pyraclostrobin $[10,13]$ can guarantee greater water use induced by an increase in root growth, assuring better growth conditions for the plants.

The results of the harvest indices are shown in Figure 8a,b. The application of pyraclostrobin resulted in an increase in both the green biomass yield and stalk yield for cultivars, RB855156 and RB867515, while only the cultivar, RB92579, did not have its yield affected by fungicide application. This result is directly related to most of the analyses, such as a higher rate of photosynthesis (Figure 2a), greater average number of green leaves (Figure 6), and larger stalk diameter (Figure 7b), which together contributed to the higher accumulation of biomass and, hence, increased yield.

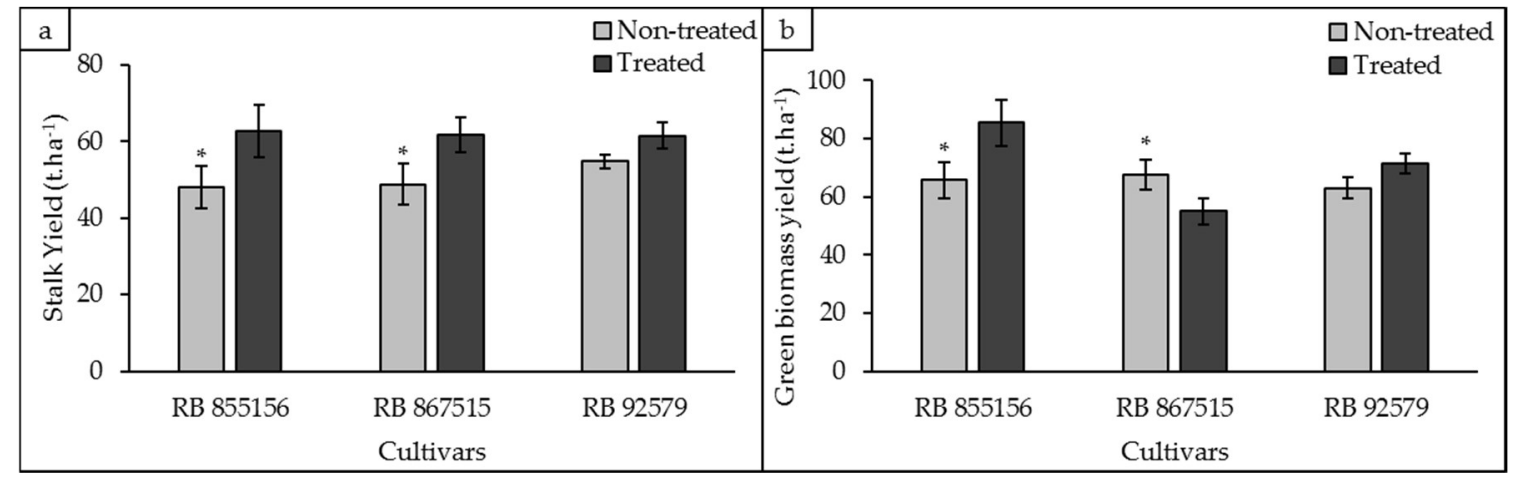

Figure 8. (a) Tons of cane per hectare (stalk yield) and (b) green biomass yield of sugarcane plants treated with pyraclostrobin and control plants. The results represent the average of three replications. * Indicates a significant difference among treatments by the Tukey test at 5\% probability. The bar indicates the standard error of the mean.

It should be emphasized that the results obtained in this experiment are not intended to promote the use of pyraclostrobin only to induce an increase in crop productivity, but rather to establish possibilities for management strategies that aim to control diseases along with a set of appropriate practices to achieve high yields.

\section{Conclusions}

Application of pyraclostrobin increased the rate of photosynthesis in three sugarcane cultivars and increased the stomatal conductance, transpiration, and nocturnal respiratory in the cultivar, RB855156.

The enzymes of the antioxidant system (SOD, CAT and APX) showed greater activity in plants treated with the fungicide in relation to non-treated plants.

Application of pyraclostrobin to sugarcane plants from the cultivars, RB855156 and RB867515, led to a significant increase in stalk yield and green biomass yield.

The highest results obtained in yield and biomass are directly related to the other effects of pyraclostrobin application observed, such as higher photosynthesis rate, higher average number of green leaves, and larger stem diameter.

Author Contributions: A.M.L. and A.C.-J. conceived and designed the experiments; A.M.L. and A.T.P.M. performed the experiments; A.M.L. and P.V.S. analyzed the data; A.C.-J. contributed reagents/materials; A.M.L., P.V.S. and A.P.d.C.N. wrote the paper.

Funding: This research received no external funding.

Acknowledgments: This research was supported by Coordenação de Aperfeiçoamento de Pessoal de Nível Superior and Universidade Federal de Lavras (UFLA). 
Conflicts of Interest: The authors declare no conflict of interest.

\section{References}

1. Berndes, G.; Hoogwijk, M.; van den Broek, R. The contribution of biomass in the future global energy supply: A review of 17 studies. Biomass Bioenergy 2003, 25, 1-28. [CrossRef]

2. Haberl, H.; Beringer, T.; Bhattacharya, S.C.; Erb, K.-H.; Hoogwijk, M. The global technical potential of bio-energy in 2050 considering sustainability constraints. Curr. Opin. Environ. Sustain. 2010, 2, $394-403$. [CrossRef] [PubMed]

3. Nogueira, L.A.H.; Lora, E.E.S. Dendroenergia: Fundamentos e Aplicaçôes; Editora Interciência: Rio de Janeiro, Brazil, 2003.

4. Karp, A.; Shield, I. Bioenergy from plants and the sustainable yield challenge. New Phytol. 2008, 179, 15-32. [CrossRef] [PubMed]

5. Waclawovsky, A.J.; Sato, P.M.; Lembke, C.G.; Moore, P.H.; Souza, G.M. Sugarcane for bioenergy production: An assessment of yield and regulation of sucrose content. Plant Biotechnol. J. 2010, 8, 263-276. [CrossRef] [PubMed]

6. Inman-Bamber, N.; Smith, D. Water relations in sugarcane and response to water deficits. Field Crops Res. 2005, 92, 185-202. [CrossRef]

7. Meschede, D.; Velini, E.D.; Carbonari, C.A.; Silva, J. Alteração fisiológica da cana-de-açúcar pela aplicação de glyphosate e sulfumeturon-methyl. Planta Daninha 2011, 29, 413-419. [CrossRef]

8. Balba, H. Review of strobilurin fungicide chemicals. J. Environ. Sci. Health 2007, 42, 441-451. [CrossRef] [PubMed]

9. Venancio, W.S.; Rodrigues, M.A.T.; Begliomini, E.; de Souza, N.L. Physiological effects of strobilurin fungicides on plants. Publicatio UEPG: Ciências Exatas e da Terra, Agrárias e Engenharias 2003, 9. [CrossRef]

10. Kanungo, M.; Joshi, J. Impact of pyraclostrobin (f-500) on crop plants. Plant Sci. Today 2014, 1, $174-178$. [CrossRef]

11. Bartett, D.W.; Clough, J.M.; Godfrey, C.R.; Godwin, J.R.; Hall, A.A.; Heaney, S.P.; Maund, S.J. Understanding the strobilurin fungicides. Pesticide Outlook 2001, 12, 143-148. [CrossRef]

12. Sauter, H.; Ammerman, E.; Benoit, R.; Brand, S.; Gold, R.E.; Grammenos, W.; Köhl, H.; Lorenz, G.; Muller, B.; Röhl, F.; et al. Mitochondrial respiration as a target for antifungals: Lessons learned from research on strobilurins. In Antifungal Agents—Discovery and Mode of Action; Dixon, G.K., Copping, L.G., Hollowman, D.W., Eds.; BIOS: Oxford, UK, 1995; pp. 173-191.

13. Köhle, H.; Grossmann, K.; Jabs, T.; Gerhard, M.; Kaiser, W.; Glaab, J.; Conrath, U.; Seehaus, K.; Herms, S. Physiological effects of the strobilurin fungicide $\mathrm{f} 500$ on plants. In Modern Fungicides and Antifungal Compounds III; Dehne, H.-W., Ed.; AgroConcept: Bonn, Germany, 2002; pp. 61-74, ISBN 3786201447.

14. Bartlett, D.W.; Clough, J.M.; Godwin, J.R.; Hall, A.A.; Hamer, M.; Parr-Dobrzanski, B. The strobilurin fungicides. Pest Manag. Sci. 2002, 58, 649-662. [CrossRef] [PubMed]

15. Fagan, E.B.; Dourado Neto, D.; Vivian, R.; Franco, R.B.; Yeda, M.P.; Massignam, L.F.; Oliveira, R.F.D.; Martins, K.V. Efeito da aplicação de piraclostrobina na taxa fotossintética, respiração, atividade da enzima nitrato redutase e produtividade de grãos de soja. Bragantia 2010, 69, 771-777. [CrossRef]

16. Barbosa, K.A.; Fagan, E.B.; Casaroli, D.; de Carvalho Canedo, S.; Teixeira, W.F. Aplicação de estrobilurina na cultura do milho: Alterações fisiológicas e bromatológicas. Revista do Centro Universitário de Patos de Minas 2011, 2178, 7662 .

17. Nelson, K.A.; Meinhardt, C.G. Foliar boron and pyraclostrobin effects on corn yield. Agron. J. 2011, 103, 1352-1358. [CrossRef]

18. Costa, R.V.D.; Cota, L.V.; Silva, D.D.D.; Meirelles, W.F.; Lanza, F.E. Viabilidade técnica e econômica da aplicação de estrobilurinas em milho. Trop. Plant Pathol. 2012, 37, 246-254. [CrossRef]

19. Reboita, M.S.; Rodrigues, M.; Silva, L.F.; Alves, M.A. Aspectos clim ticos do estado de minas gerais (climate aspects in minas gerais state). Revista Brasileira de Climatologia 2015, 17. [CrossRef]

20. Biemelt, S.; Keetman, U.; Albrecht, G. Re-aeration following hypoxia or anoxia leads to activation of the antioxidative defense system in roots of wheat seedlings. Plant Physiol. 1998, 116, 651-658. [CrossRef] [PubMed] 
21. Giannopolitis, C.N.; Ries, S.K. Superoxide dismutases: I. Occurrence in higher plants. Plant Physiol. 1977, 59, 309-314. [CrossRef] [PubMed]

22. Mengutay, M.; Ceylan, Y.; Kutman, U.B.; Cakmak, I. Adequate magnesium nutrition mitigates adverse effects of heat stress on maize and wheat. Plant Soil 2013, 368, 57-72. [CrossRef]

23. Nakano, Y.; Asada, K. Hydrogen peroxide is scavenged by ascorbate-specific peroxidase in spinach chloroplasts. Plant Cell Physiol. 1981, 22, 867-880.

24. Arnon, D.I. Copper enzymes in isolated chloroplasts. Polyphenoloxidase in beta vulgaris. Plant Physiol. 1949, 24, 1-15. [CrossRef] [PubMed]

25. Lichtenthaler, H.K. Chlorophylls and carotenoids: Pigments of photosynthetic biomembranes. In Methods in Enzymology; Moore, B.S., Ed.; Academic Press: Cambridge, MA, USA, 1987; Volume 148, pp. 350-382.

26. Grossmann, K.; Retzlaff, G. Bioregulatory effects of the fungicidal strobilurin kresoxim-methyl in wheat (triticum aestivum). Pestic. Sci. 1997, 50, 11-20. [CrossRef]

27. Kluge, R.A.; Tezotto-Uliana, J.V.; da Silva, P.P. Aspectos fisiológicos e ambientais da fotossíntese. Revista Virtual de Química 2014, 7, 56-73.

28. Vavasseur, A.; Raghavendra, A.S. Guard cell metabolism and co2 sensing. New Phytol. 2005, 165, 665-682. [CrossRef] [PubMed]

29. Lima, J.D.; Moraes, W.d.S.; da Silva, M.-G.; Helena, S. Respostas fisiológicas em mudas de banananeira tratadas com estrobilurinas. Semina: Ciências Agrárias 2012, 33, 77-85. [CrossRef]

30. Logan, B.A.; Adams, W.W.; Demmig-Adams, B. Viewpoint: Avoiding common pitfalls of chlorophyll fluorescence analysis under field conditions. Funct. Plant Biol. 2007, 34, 853-859. [CrossRef]

31. Gill, S.S.; Tuteja, N. Reactive oxygen species and antioxidant machinery in abiotic stress tolerance in crop plants. Plant Physiol. Biochem. 2010, 48, 909-930. [CrossRef] [PubMed]

32. Wu, Y.-X.; von Tiedemann, A. Physiological effects of azoxystrobin and epoxiconazole on senescence and the oxidative status of wheat. Pest. Biochem. Physiol. 2001, 71, 1-10. [CrossRef]

(C) 2018 by the authors. Licensee MDPI, Basel, Switzerland. This article is an open access article distributed under the terms and conditions of the Creative Commons Attribution (CC BY) license (http://creativecommons.org/licenses/by/4.0/). 